\title{
Endoscopic Transphenoidal Approach for Fibrous Dysplasia of Clivus, Tuberculum Sellae and Sphenoid Sinus; Report of Three Cases
}

\author{
Klivus, Tuberkulum Sella ve Sfenoid Sinus Fibroz Displazili Ü̧̧ Olguya \\ Endoskopik Transsfenoidal Yaklaşım
}

Ihsan ANIK, Kenan KOC, Burak CABUK, Savas CEYLAN

Kocaeli University, Faculty of Medicine, Pituitary Research Centre and Department of Neurosurgery, Kocaeli, Turkey

Correspondence address: Ihsan ANIK / E-mail: drianik@yahoo.com

\begin{abstract}
AIM: Fibrous dysplasia is a benign disease in which medullary bone is replaced by fibro-osseous tissue, and causes distortion and overgrowth of the involved bone and represents about $3 \%$ of all bone tumors. There is variability in the manifestation of Fibrous Dysplasia lesions with imaging techniques due to their proportional variations of fibrous to osseous tissue. Radiological differential diagnoses include meningioma, chordoma on MRI and Paget disease on CT imagings.

MATERIAL and METHODS: We report three cases of monostotic fibrous dysplasia, affecting clivus, tuberculum sellae, and sphenoid sinus through the pterygopalatine fossa. We performed pure endoscopic transphenoidal approach for those three cases with the guide of neuronavigation. Extended approach was used via binostril for fibrous dysplasia of clivus and Tuberculum sellae.

RESULTS: Radiologic report revealed chordoma and meningioma for the two cases and fibrous dysplasia for the last case. Total resection of tuberculum sellae, subtotal resection of clivus and partial resection of sphenoid sinus lesions were performed. Pathology diagnosis were fibrous dysplasia in all three patients.

CONCLUSION: Histopathological sampling provided by surgical approach should be obtained to establish the final diagnosis. Endoscopic approaches are convenient for skull base lesions even for biopsy or curative resections providing panoramic view and avoid brain retraction.

KEYWORDS: Clivus, Endoscopic transphenoidal approach, Fibrous dysplasia, Tuberculum sellae
\end{abstract}

öz

AMAÇ: Fibröz displazi, medüller kemikte fibroz doku gelişmesi ile etkilenen kemikte distorsiyona ve aşırı bir büyümeye neden olan ve tüm kemik tümörlerin \%3'ünü oluşturan bir kemik hastalığıdır. Fibröz dokunun yapısal farklılıklarına göre fibröz displazi lezyonları görüntüleme teknikleriyle incelendiğinde farklıık gösterirler. Radyolojik ayırıcı tanıda, Magnetik Rezonans Görüntülemede (MRG) meningioma, kordoma, Bilgisayarlı Tomografi 'de (BT) Paget hastalığı yer alır.

YÖNTEM ve GEREÇLER: Klivusu, Tuberkulum sellayı ve sfenoid sinüsten pterigopalatin fossaya kadar uzanan alanı etkileyen üç farklı fibröz displazi olgusu tartışılmıştır. Üç olgu da navigasyon eşliğinde endoskopik transsfenoidal yaklaşımla ameliyat edilmiştir. Klivus ve Tuberkulum sella olgularında iki nostril kullanılarak genişletilmiş yaklaşım uygulanmıştır.

BULGULAR: Radyolojik olarak ilk iki olgu kordoma ve meninjioma, üçüncü olgu da fibröz displazi olarak değerlendirilmiştir. Tuberkulum selladaki lezyon total, klivustaki lezyon subtotal ve sfenoid sinüsteki lezyonda parsiyel olarak çıkarılmıştır. Üç hastada da patoloji sonucu fibröz displazi olarak gelmiştir.

SONUÇ: Fibröz displazili olgularda cerrahi ile elde edilen histopatolojik örnekleme tanıyı netleştirmek için gereklidir. Kafa tabanı yerleşimli bu lezyonların gerek biyopsisinde gerekse rezeksiyonunda panoramik görüntüleme sağladığı ve beynin retraksiyonunu gerektirmediğinden, endoskopik yolla cerrahi uygun yaklaşımlardır.

ANAHTAR SÖZCÜKLER: Klivus, Endoskopik transsfenoidal yaklaşım, Fibröz displazi, Tuberkulum sella

\section{INTRODUCTION}

Fibrous dysplasia is a developmental benign disorder of the bone, which is caused by abnormal proliferation of fibroblasts. The disease is classified into three forms: monostotic, polyostotic and McCune Albright syndrome $(4,5,7,8)$.

Misdiagnosis of neuroradiologic imaging is one of the great challenges for fibrous dyplasia. Although both CT and MRI, are valuable, $\mathrm{CT}$ being more superior, the histopathological evidence obtained by surgery is required to make the definite diagnosis $(2,4-10)$.

Endoscopic transsphenoidal approach is an easier and minimal invasive procedure especially for tuberculum sellae and clivus lesions, which are difficult to reach by transcranial approach $(1,3,7)$. 
We report three cases of monostotic fibrous dysplasia, affecting clivus, tuberculum sellae, and sphenoid sinus through the pterygopalatine fossa, which were operated on by pure endoscopic transphenoidal approach and discussed the neuroradiologic misdiagnosis of these cases.

\section{Case 1: Fibrous Dysplasia of Clivus}

A 47 year-old male presented with headache for two months. Neurological and physical examination were normal. MRI revealed solid mass lesion expanded left part of the clivus showing decreased signal on T1 weighted and increased signal on T2 weighted images was seen. Contrast enhancement was observed after contrast media injection. Chordoma or chondrosarcoma was the initial radiological differential diagnosis (Figure 1A,B).

\section{Case 2: Fibrous Dysplasia of Tuberculum Sellae}

A 30 year-old female presented with headache, irregular menstrual cycles, and galactorrhoea. Her endocrine tests confirmed raised PRL level to $340 \mathrm{ng} / \mathrm{ml}$. There was no adenoma apparent within the pituitary gland. Other pituitary function tests were normal and there was not any medication causing hyperprolactinaemia. Endocrinology department assigned medical treatment for hyperprolactinaemia.

On MRI, mass lesion of $2 \times 1 \mathrm{~cm}$ dimensions located at tuberculum sellae was seen. The lesion was hypointense on T1 weighted, hyperintense on T2 weighted images and dense contrast enhancement was observed on contrast-enhanced images (Figure 1 C, D). Radiological diagnosis was en plaque meningioma.

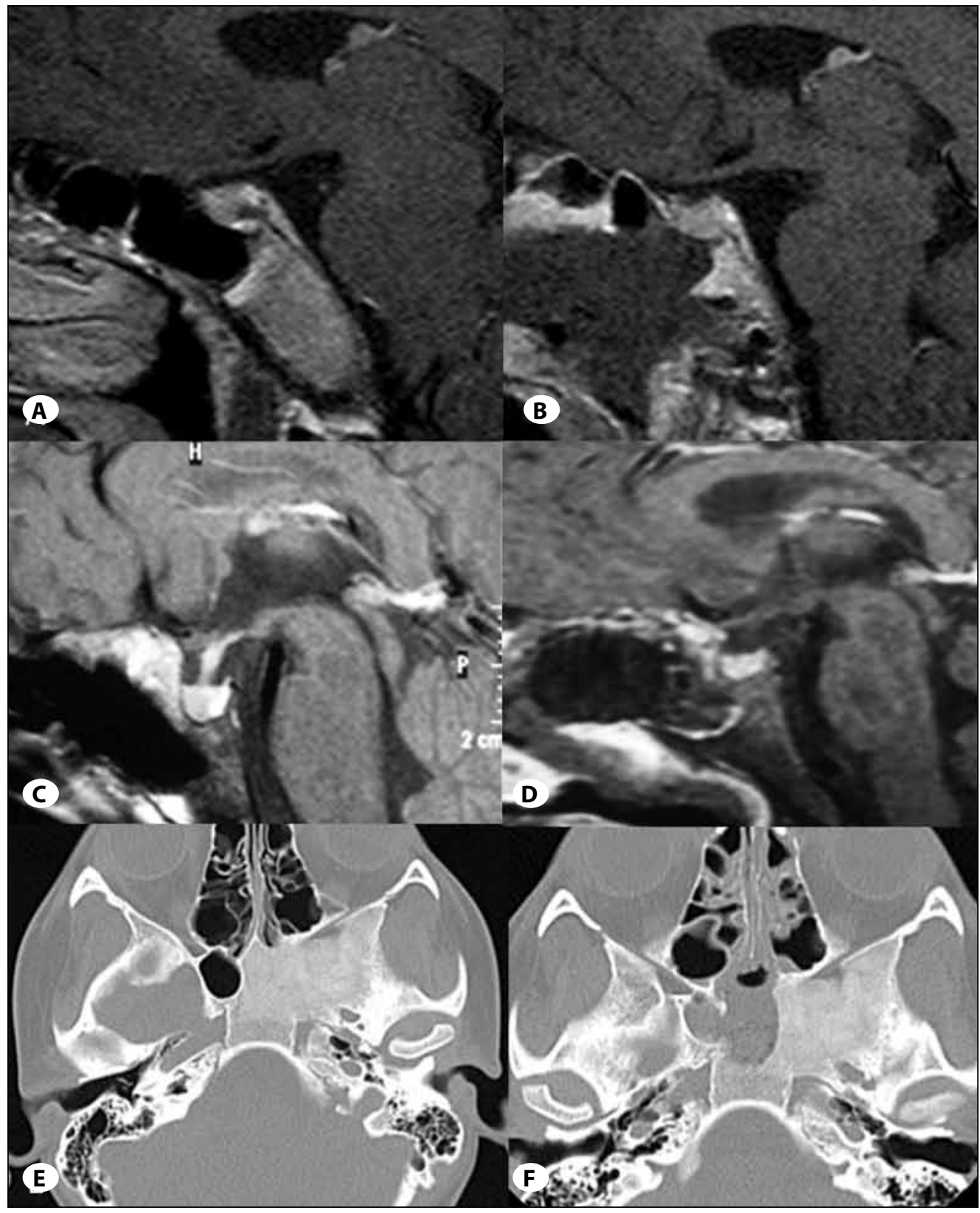

Figure 1: A) Preoperative contrast enhanced sagittal T1 weighted MR image demonstrates contrast enhanced mass lesion expanding clivus. B) Postoperative contrast enhanced T1 weighted image demonstrates removal of the lesion. C) Lesion with the significant contrast enhancement is seen at tuberculum sellae on preoperative contrast enhanced sagittal T1 weighted image.

D) Postoperative contrast enhanced sagittal image demonstrates postoperative changes.

E) Lesion causing expansion of the left wall of sphenoid sinus extending to pterygopalatine fossa is seen on axial CT image. Note that the affected part of the bone is ground glass density.

F) Postoperative axial CT image reveals bone defect of the sphenoid sinus wall following partial resection. 


\section{Case 3: Fibrous Dysplasia of Sphenoid Sinus and Pterygopalatine Fossa}

Fifteen year-old girl had a history of syncope. Her neurological and physical examination was normal. Multislice (64 detector) computed tomography revealed a lesion of ground glass density causing expansion that is located at the left wall of sphenoid sinus extending to pterygopalatine fossa (Figure 1 E, F).

Neurological and physical examinations of all cases were normal. The symptoms of the patients were all non-specific which cannot be related to the lesions.

\section{Surgical Approaches:}

Surgical procedures were performed by extended approach. Neuronavigation was used to verify anatomic landmarks in all cases.

Patient was placed supine fixed by Mayfield and turned slightly on a horizontal plane toward the surgeon and the head extended slightly on the sagittal plane. The procedures were performed using a rigid endoscope (Karl Storz, Tuttlingen, Germany). In cases with clivus and tuberculum sellae lesions, after viewing choana, and sphenoethmoid recess, middle turbinate was resected partially in the right nostril and middle turbinate of the other nasion was lateralized for binostril approach.
For the clivus lesion; anterior sphenoidotomy was performed from inferior border of ostium by microdrill. We extended the bone removal to the posterior portion of the vomer and the sphenoidal floor to access the lower clivus. The borders of the clivus were defined with the aid of neuronavigation.

For the tuberculum sellae lesion; anterior sphenoidotomy was performed removing posterior nasal septum, rostrum and perpendicular lamina by microdrill. Sellar floor, opticocarotid recess, tuberculum sellae and planum sphenoidale were visualized.

After defining dysmorphic bone structure involving the clivus and tuberculum sellae, resection of the lesions were performed using high speed drill, curettes and punch (Figure $2 \mathrm{~A}-\mathrm{C})$.

For the sphenoid sinus lesion; the surgical approach was performed through the left nostril. After pushing the middle turbinate laterally, choana and sphenoid ostium were defined. Sphenoid ostium was expanded medially with highspeed drill. Unaffected right sphenoid sinus was observed to define normal anatomic structures. Neuronavigation was used to define lateral border of the lesion. Dysplastic bone was resected with curettes and punch for a while to get pathologic sampling and then high-speed drill was used for partial removal of the component, which filled the sphenoid sinus (Figure 2 D).

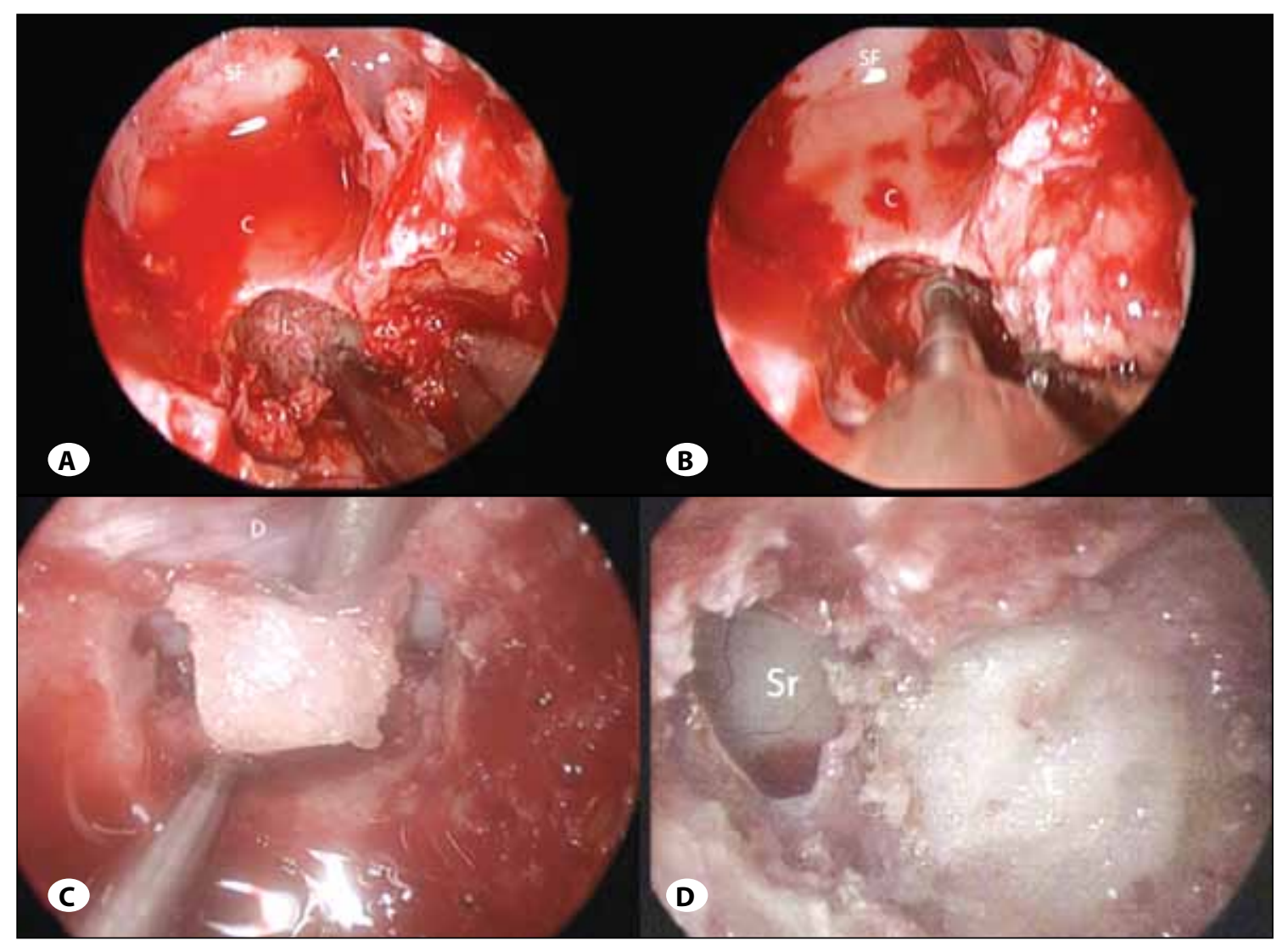

Figure 2: Intraoperative view of the lesion removal. Fibrous Dysplasia of Clivus (A,B), Tuberculum Sellae (C) and Sphenoid Sinus (D). SF: Sella Floor, C: Clivus, D: Dura over the tuberculum sellae, Sr: Right Sphenoid Sinus, L: Lesion. 
In the first case with clival lesion, we realized the misdiagnosis during the surgery and ended the operation after exposing the posterior borders. In the second case with tuberculum sellae lesion, we had to perform total removal of the lesion to clarify the absence of the meningioma.

\section{RESULTS}

In our first case of clival fibrous dysplasia, radiological report revealed chordoma as a first diagnosis. In the second case of tuberculum sellae fibrous dsyplasia, the lesion was thought to be meningioma radiologically. In the third case radiological findings revealed fibrous dysplasia as the first diagnosis. Total resection for tuberculum sella, subtotal resection for clivus and partial resection for sphenoid sinus lesions were performed. Pathologic diagnosis were fibrous dysplasia in all three patients.

The patients were followed up for 24 months for the tuberculum sellae lesion, 16 months for sphenoid sinus lesion, and 16 months for clival lesion. There were no morbidities or mortalities.

\section{DISCUSSION}

Fibrous dysplasia is a benign disease in which medullary bone is replaced by fibro-osseous tissue, and causes deformation and overgrowth of the involved bone. There is a small risk of malignant transformation for fibrous dysplasia being osteosarcoma, fibrosarcoma and chondrosarcoma. Surgical removal is indicated to define the histological diagnosis and to treat any bony deformity or cranial nerve compression $(4,8)$.

Radiotherapy is not advised for fibrous dysplasia since there is a risk of malignant transformations due to adjuvant radiotherapy. Long-term clinical and radiological follow-up is necessary $(4,7)$.

In the literature three types of fibrous dysplasia were described. Monostotic form is mostly seen with about $70 \%$ involving the long bones like femur and tibia. Clivus is a rarely affected site for monostotic fibrous dyplasia and to our knowledge fibrous dysplasia of tuberculum sellae is not reported. Multiple bone involvement (Polyostotic form) is a less common form of fibrous dysplasia (30\%), and the third is polyostotic form with McCune Albright syndrome $(4,8)$.

There is variability in the manifestation of fibrous dysplasia lesions with imaging techniques due to their proportional variations of fibrous to osseous tissue. Fibrous dysplasia shows low signal intensity on T1-weighted images, while the signal intensity on T2-weighted images varies from high to intermediate or low cellularity, depending on collagen content, extent of bone trabeculae, and cyst formation. In fibrous dysplasia, a relatively typical finding on $\mathrm{CT}$ is an amorphous ground glass appearance $(2,6,8)$.

Radiological differential diagnoses include chordoma, meningioma (9), and Paget disease (10). On CT scans, skull lesions of fibrous dysplasia (FD) may often be misdiagnosed with Paget disease (PD). Tehranzadeh et al defined that FD and PD of the skull has similar signs on CT scans that can be diagnostically confusing. They tried to differentiate the dissimilar features of FD and PD (10).

In our first case of clival fibrous dysplasia, radiological report revealed chordoma as a first diagnosis and in the second case of tuberculum sellae fibrous dysplasia, the lesion was thought to be meningioma radiologically. In the third case radiological findings revealed fibrous dysplasia as the first diagnosis. In the first two cases, since radiological reports did not specify fibrous dysplasia in the differential diagnosis, we did not perform CT scans of the patients.

The transphenoidal route has been the preferred approach in previous cases of clival fibrous dysplasia, mostly with traditional microscopic technique $(1,4)$. Singh et al $(7)$ and Gonçalves et al (3) published one case of endoscopic transphenoidal approach for fibrous dysplasia of clivus.

Transcranial approaches to the skull base have higher mortalities and morbidities than the other anatomical areas, and following the patients without surgery for benign lesions of the skull base may therefore be an alternative aspect.

Endoscopic approach is a minimal invasive for the regions which is more difficult to reach by transcranial approaches. This approach provides the most direct anatomic trajectory to these regions and eliminates the need for an extensive lateral skull base approach. Endoscopic approaches are convenient for fibrous dysplasia of skull base even for biopsy or curative resections providing panoramic view and identifying the borders of the lesion better than microscopic approaches. We suggest performing the endoscopic approach to provide the definite diagnosis for these lesions even in clinically silent patients considering the advances in surgical procedures and neuronavigation.

We have performed endoscopic transphenoidal approach for all three cases. Head position is important in these cases since extension of the head is appropriate for tuberculum sellae lesion while head position should be decided due to position of clivus for clival lesions. Extended approaches should be performed for clival and tuberculum sellae lesions. Removal to the posterior portion of the vomer for clival lesions and perpendicular lamina for tuberculum sellae are required to access the surgical field. The binostril approach for extended procedures has the advantage of using 3-4 hands simultaneously.

One of the difficulties of this approach for fibrous dysplasia is to identify surgical landmarks because the lesion destroys the borders of landmarks especially for clival lesions and sphenoid sinus involvements. This difficulty can be overcome with the aid of neuronavigation and gaining experience with the endoscopic transphenoidal surgery.

\section{CONCLUSION}

In skull base lesions, CT and MRI should be both performed to avoid misdiagnosis. However, histopathological sampling provided by surgical approach should be definitely obtained to establish the final diagnosis for fibrous dysplasia. 
Endoscopic transphenoidal surgery is, standard or extended, simple and minimally invasive and should be the preferred procedure especially for the regions that are difficult to reach by transcranial approaches. Furthermore, total resection can be used in clinically symptomatic cases.

\section{REFERENCES}

1. Adada B, Al-Mefty O: Fibrous dysplasia of the clivus. Neurosurgery 52: 318-322, 2003

2. Daffner RH, Kirks DR, Gehweiler JA Jr, Heaston DK: Computed tomography of fibrous dysplasia. AJR 139:943-948, 1982

3. Gonçalves MB, Siqueira SB, Christoph DH, Klescoski J, Melo $\mathrm{MH}$, Landeiro JA: Monostotic fibrous dysplasia of the clivus: Image-guided endoscopic endonasal transsphenoidal surgery. Minim Invasive Neurosurg 53(1): 37-39, 2010

4. Levy M, Chen T, Weiss M: Monostotic fibrous dysplasia of the clivus. J Neurosurg 75:800-803, 1991
5. Li P, Zhang ZR, Jiang Y, Xia XD, Wang D, Li XF: MR and CT findings of cyst degeneration of sphenoid bone in McCuneAlbright syndrome: A case report. Cases J 22(2):9376, 2009

6. Norris MA, Kaplan PA, Pathria M, Greenway G: Fibrous dysplasia: Magnetic resonance imaging appearance at 1.5 tesla. Clin Imaging 14:211-215, 1990

7. Singh N, Abou-Zeid A, King A, du Plessis D, Gnanalingham $\mathrm{K}$ : Endoscopic transsphenoidal surgery for isolated fibrous dysplasia of the clivus. Minim Invasive Neurosurg 52(4): 190-192, 2009

8. Sirvanci $M$, Karaman $K$, Onat L, Duran C, Ulusoy OL: Monostotic fibrous dysplasia of the clivus: MRI and CT findings. Neuroradiology 44:847-850, 2002

9. Sutton D: Textbook of Radiology and Imaging. 6th ed. New York: Churchill Livingstone, 1998

10. Tehranzadeh J, Fung Y, Donohue M, Anavim A, Pribram HW: Computed tomography of Paget disease of the skull versus fibrous dysplasia. Skeletal Radiol 27(12):664-672, 1998 